\title{
Earnings Discontinuity as the Proxy for Earnings Management: Empirical Study from the UK, Germany and the Czech Republic
}

\author{
Jan Svitlik - Marcela Zárybnická Žárová*
}

\begin{abstract}
:
The paper deals with the phenomenon of earnings discontinuity around zero level in the UK, as the common law representative, Germany, as the civil law representative, and the Czech Republic, as the civil law representative where earnings management research has not yet been thoroughly realized. We undertake both cross-sectional and time-series analysis from 2006 to 2013. According to our findings, the UK is a low-earnings-management country with slightly decreasing trend of the earnings management level. On the other hand, earnings management engagement in Germany and the Czech Republic is of a significantly higher level than in the UK. Moreover, Czech companies suggest an increasing trend of the earnings management level. We find significant difference between the common law representative and the civil law ones in terms of the earnings management level.
\end{abstract}

Key words: Earnings Management; Earnings Discontinuity; Czech Republic; United Kingdom; Germany.

JEL classification: M41 .

\section{Introduction}

We choose three European countries, the UK, Germany and the Czech Republic with different legal systems for the purpose of investigation. As summarized in the literature review, legal system is considered by many researchers as the dominant factor that has influence on the nature of accounting regulation in the given country. Legal system that relies upon a limited amount of statute law, which is then interpreted by courts and which builds up large amounts of case law to supplement the statutes, is known as common law (Nobes and Parker, 2012) and was formed in England. This law influences commercial law which traditionally does not prescribe detailed rules for accounting which may be in the form of standards or recommendations and accountants themselves establish rules for

\footnotetext{
Jan Svitlík; University of Economics, Prague, Faculty of Finance and Accounting, Department of Financial Accounting and Auditing, W. Churchill Sq. 4, 13067 Prague 3, Czech Republic, <xsvij10@vse.cz>.

Marcela Zárybnická Žárová; University of Economics, Prague, Faculty of Finance and Accounting, Department of Financial Accounting and Auditing, W. Churchill Sq. 4, 13067 Prague 3, Czech Republic, <zarova@vse.cz>.

The article is processed as an output of a research project under the registration number IP100040.
} 
accounting practice. On the contrary, there are countries in Europe where the system of law is based on the codified Roman law system or civil law, where governments pass laws that regulate financial reporting and legitimacy and social acceptance of the rules for financial reporting are assured. This seems to be advantageous to this system, but Bromwich and Hopwood (1992) warn that setting the rules of financial reporting by law suffers from a number of disadvantages. As legislators, in general, do not give priority to laws concerning financial reporting, such laws are often enacted after considerable delays, so that by the time they come into force, they are already out of date. Moreover, Bromwich and Hopwood (1992) criticise that financial reporting regulated by law is too detailed and there is therefore danger that its provisions are inappropriate.

There are two main objectives of this paper. First, to analyse whether the level of earnings management of companies in the UK, the common law representative, are different of those in Germany and the Czech Republic, the civil law representatives. Second, to analyse the recent development of the earnings management level in these three European economies. To accomplish the objectives, we undertake both the cross-sectional and time-series empirical analysis of earnings distribution in the UK, Germany and the Czech Republic from 2006 to 2013.

The paper is structured as follows. Section two summarizes relevant literature and states research hypotheses. Section three describes data and methodology applied. Section four contains cross-sectional analysis of earnings distribution. Time-series analysis of earnings distribution is covered in section five. Overall results are provided in section six. Section seven concludes.

\section{Literature Review}

According to Roberts et al. (2005) there are six different features of a country which give rise to different accounting systems: the political and economic system, the legal system, the taxation system, the corporate financing system, the accounting profession, and religion.

Hermida (2004) explains how and in which characteristics common law and civil law made progress from historically distinct systems to relatively integrated systems in present. He explains that gradual convergence process between common law and civil law has its origins in the Age of Enlightenment in the $18^{\text {th }}$ century. From that period on, common law and civil law systems were strongly mutually influenced. As Hermida (2004, pp. 4) claims: "This process toward convergence does not mean that civil law and common law are one and the same. On the contrary, there are still important differences in virtually every area of these two systems. However, these differences mainly deal with a different order of priority in sources, i.e. civil law gives predominance to doctrine (including the 
codifiers' reports) over jurisprudence, while the opposite is true in the common law." He also acknowledges that compared to other traditions, such as Talmudic, Islamic, Hindu or Asian, similarities of common law and civil law are much greater than its differences. Finally, Hermida (2004, pp. 32) concludes: "At the present stage of development towards convergence in the contract field, despite these differences in style, methodology and terminology, common law and civil law have arrived at practically analogous solutions for the vast majority of contract problems." Lindahl and Schadewitz (2013), similar to Hermida (2004), infer that historically distinct common law and civil law systems have been strongly converging over past decades, especially within Europe. Moreover, they claim there are rather differences on the national level than between legal families, i.e. common law countries and civil law countries, unlike inferences of e.g. La Porta et al. (1998).

Altintas and Yilmaz (2012) find following differences of common law and civil law systems. Common law system relies more on courts decisions than on statute law, while the opposite holds for civil law system. Common law is more specific and particular compared to rather abstract and general civil law. Accounting practice is regulated through recommendations and standards under common law countries, while under civil law, accounting is integral part of law. Dainow (2013) claims that although the solutions of particular cases are similar under common law and civil law nowadays, the methods and processes used to come to such results are still of great difference, e.g. the precedent concept is not usually taken into consideration under civil law. Another example of distinctive feature is presence of jury and greater emphasis of oral testimony of witnesses under common law, while documents play major role under civil law system (Messitte, 1999).

In the UK, private and institutional shareholders are main providers of share capital, while banks and other financial institutions are dominant source of capital in Germany (Day, 2000). Jindrichovska (2004), in compliance with Day (2000), asserts that in civil law countries, such as Germany and France, banks are the primary supplier of funds, while in common law countries, such as the UK and the US, companies are mostly financed through stock exchanges. The level of cooperation between tax accounting and financial accounting is another difference between the UK and most European countries. In majority of European countries taxation rules historically preceded accounting practice; therefore, accounting is fairly influenced by taxation system. Such high book-tax alignment is typical for civil law countries. By contrast, UK accounting system is older and developed apart from taxation system (Day, 2000). That is why the UK is generally perceived as low book-tax alignment country. 
Svitlík, J. - Žárová, M.: Earnings Discontinuity as the Proxy for Earnings Management: Empirical Study from the UK, Germany and the Czech Republic.

Marinakis (2011, pp. 29) defines earnings management as follows: "The result of managerial discretion in accounting choices and estimates exercised within the limits of accounting standards without violating true and fair view principle.", while he defines earnings manipulation as "The result of managerial actions that violate the true and fair principle and fail to comply with the accounting standards." He also states that there have been three main earnings management research approaches in the literature so far, namely, discretionary accruals models, specific accruals models, and conditional distributions. Using sample of 9,809 UK firm-years, his paper suggests that unusual distribution of earnings around zero level might be good indicator for earnings management. In particular, high frequency of small profits and simultaneous low frequency of small losses suggests earnings management activity of companies. Hayn (1995), Kang (1999), Harris and Shi (2014) claim that unusually low concentration of earnings just below zero and unusually high concentration of earnings just above zero is the feature of earnings management. Moreira and Pope (2007) investigate firms which suffer negative returns in one accounting period and find higher frequency of small profits in case of these firms compared to firms with positive returns. This suggests that firms with slightly negative pre-managed earnings endeavour to increase their earnings just above zero level; this holds in the greatest extent for highly leveraged firms.

Aussenegg et al. (2009) apply 15 different measures of earnings management on a dataset of European public traded firms. Among others, they find lower earnings management activities in the UK and Northern Europe than in the rest of European countries. Coppens and Peek (2005) investigate distribution characteristics of earnings in eight European countries and they do not find loss avoidance evidence of private firms in Germany and France. On the other hand, they find earnings management in form of loss avoidance in case of five other European countries (Belgium, Denmark, Italy, Netherlands, Spain and the UK). Geurts (2010) uses methodology of Coppens and Peek (2005). Her study suggests that private companies in both civil law countries (high book-tax alignment countries) and common law countries (low book-tax alignment countries) manage earnings to avoid small losses. She finds such evidence also for European public companies. Her findings also indicate that firms in civil law countries more often use earnings management to avoid small losses than their common law counterparts. Burgstahler, Hail and Leuz (2014) find that private firms engage more in earnings management than public firms. They also infer, unlike Coppens and Peek (2005), that private firms in high book-tax alignment countries (civil law countries) exhibit more earnings management than firms in low book-tax alignment countries (common law countries); this does not fully hold for public firms. Their findings in terms of common law vs. civil law countries are basically in line with Geurts (2010). 
The prior research mainly asserts diminishing differences between common law and civil law countries. Regarding the level of earnings management in common law countries and civil law ones, the evidence is rather mixed. This leads us to following two null hypotheses.

\section{H1: There is no significant difference between common law and civil law countries regarding the earnings management level.}

\section{H2: Earnings management level is decreasing both in common law and civil law countries from 2006 to 2013.}

\section{Data and Methodology}

We undertake micro backward-looking methodology of empirical research using Bureau van Dijk - Amadeus database ${ }^{1}$. The earnings discontinuity model introduced by Burstahler and Dichev (1997) is followed as the primary model of our research design. The authors of the model notice that scaled earnings exhibit phenomenon of discontinuity around zero level. They attribute such phenomenon to earnings management. Numerous researchers have been investigating earnings discontinuity around zero level based on model of Burgstahler and Dichev. For instance, Hayn (1995), Kang (1999), Harris and Shi (2014) infer that unusual high relative frequency of profits just above zero level is caused by earnings management of companies. The theory behind is that firms with ex-ante (premanaged) small negative earnings make every effort to avoid the red numbers which would otherwise trigger concerns of shareholders, creditors or other business associates. Strong motivation towards positive earnings makes firms engage in earnings management in order to increase earnings over zero level. Such behaviour leads to low relative frequency of small losses and high relative frequency of small profits within companies which manage their earnings upwards to beat zero level. Therefore, earnings distribution around zero level serves researchers as powerful tool of earnings management detection.

Additionally, we employ methodology of Leuz et al. (2003) in calculation of small profits to small losses ratio as the auxiliary tool of our research. Use of the additional tool enhances robustness of our results.

Our initial data sample of companies from the United Kingdom, Germany and the Czech Republic from 2006 to 2013 was adjusted in order to get representative final sample for our research questions. We focus on the time period of 2006-2013 as the broadest period available in the database without substantially lower number of data for particular financial years. First, we keep only 12-months financial-year data of active firms because calculation of the ratios based on non-standard

1 The access to the database is limited to very large, large and medium-size companies; therefore, small companies are missing in the sample. 
Svitlík, J. - Žárová, M.: Earnings Discontinuity as the Proxy for Earnings Management: Empirical Study from the UK, Germany and the Czech Republic.

financial years or non-active firms might bias the results. Second, firms-years with total assets (A) or earnings after taxes (EAT) equal to zero or missing were dropped. Third, only national GAAP financial statements data were kept; in other words, we drop all IFRS data. ${ }^{2}$ Finally, we dropped financial and insurance sector firms (NACE 6400-6699) because these institutions are usually subject to different accounting regulation. Our final sample counts 625,643 firm-years from the United Kingdom, 383,500 firms-years from Germany, and 263,672 firm-years from the Czech Republic (see details in Table 1). The final sample of each financial year of each country was winsorized at $1 \%$ level to eliminate outliers.

Tab. 1 Breakdown of the final sample: number of firm-years

\begin{tabular}{lrrrr}
\hline Year & Czech Republic & Germany & The UK & Total \\
\hline 2006 & 25,217 & 42,933 & 63,186 & 131,336 \\
2007 & 29,110 & 43,001 & 67,775 & 139,886 \\
2008 & 32,616 & 45,854 & 72,749 & 151,219 \\
2009 & 35,179 & 49,340 & 77,567 & 162,086 \\
2010 & 36,546 & 53,552 & 79,302 & 169,400 \\
2011 & 37,159 & 57,957 & 83,184 & 178,300 \\
2012 & 36,652 & 57,129 & 88,308 & 182,089 \\
2013 & 31,193 & 33,734 & 93,572 & 158,499 \\
\hline Total & 263,672 & 383,500 & 625,643 & $1,272,815$ \\
\hline
\end{tabular}

Source: Author using Bureau van Dijk - Amadeus database.

Apart from earnings distribution, other techniques of earnings management detection appear in the literature. Econometric models based on the Jones model invented by Jones (1991) and the so-called modified Jones model (or DSS model) published by Dechow, Sloan and Sweeney (1995) have made the base for a number of modifications and alternatives in the following two decades. As probably every theoretical model, Jones-based approach has its defenders and opponents; and thus, pros and cons. So does earnings distribution methodology used in our paper.

Mikova (2015) uses Jones-based model in her dissertation to investigate IFRS adoption influence on earnings quality of 15 public companies in the Czech Republic from 1993 to 2013. We use different methodology and much broader data set in the paper. Limited scope of our paper does not leave us space to use

2 National GAAP data and IFRS data are basically incomparable. 
more earnings-management detection approaches; therefore, earnings distribution methodology is used to answer our research questions.

\section{Cross-sectional Analysis of Earnings Distribution}

We exploit methodology of Burgstahler and Dichev (1997) to undertake crosssectional analysis and further time-series analysis of earnings discontinuity around zero level. First, scaled earnings (EAT/A ratio ${ }^{3}$ ) for all firms within each financial year and each country are calculated. Second, we arrange bins of equal width to sort out scaled earnings. In compliance with Burgstahler and Dichev, bins of 0.005 width are used. Finally, we calculate relative frequencies of scaled earnings within individual bins, while our concentration is focused on the zero-level adjacent bins (first positive and first negative bin).

To investigate $\mathrm{H} 1$, we compare earnings distribution around zero level in the United Kingdom, Germany and the Czech Republic for all eight financial years. Results of 2013 are used as tabulated representative while similar characteristics are found for all financial years during the 2006-2013 period.

Figure 1 indicates significant change in relative frequency between the first negative and the first positive bin in Germany which suggests a relatively high level of managed earnings. On the other hand, Figure 2 shows that earnings distribution in the UK tends to normal distribution of earnings around zero level suggesting a relatively low level of managed earnings. Figure 3 depicts earnings distribution around zero level in the Czech Republic. Although the part rightwards from zero resembles normal distribution, the part leftwards from zero depicts substantially different characteristics. The jump from negative to positive numbers indicates relatively high earnings management engagement in the Czech Republic.

3 EAT - Earnings After Taxes (net earnings), A - Total Assets. 
Svitlík, J. - Žárová, M.: Earnings Discontinuity as the Proxy for Earnings Management: Empirical Study from the UK, Germany and the Czech Republic.

Fig. 1 Germany 2013: Relative frequency of EAT/A bins (\% points)

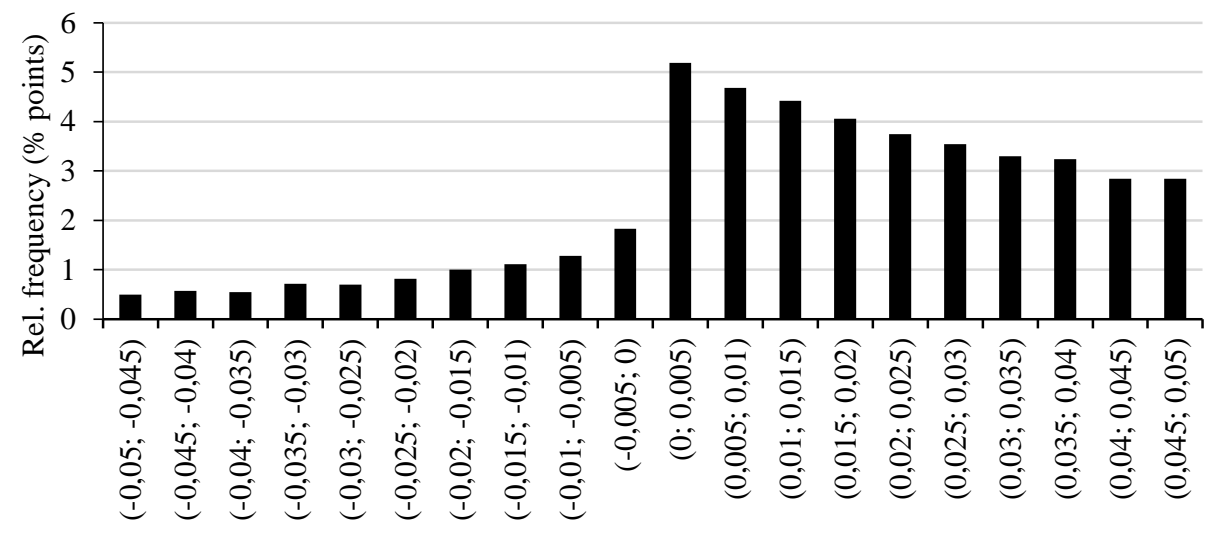

Source: Author.

Fig. 2 The UK 2013: Relative frequency of EAT/A bins (\% points)

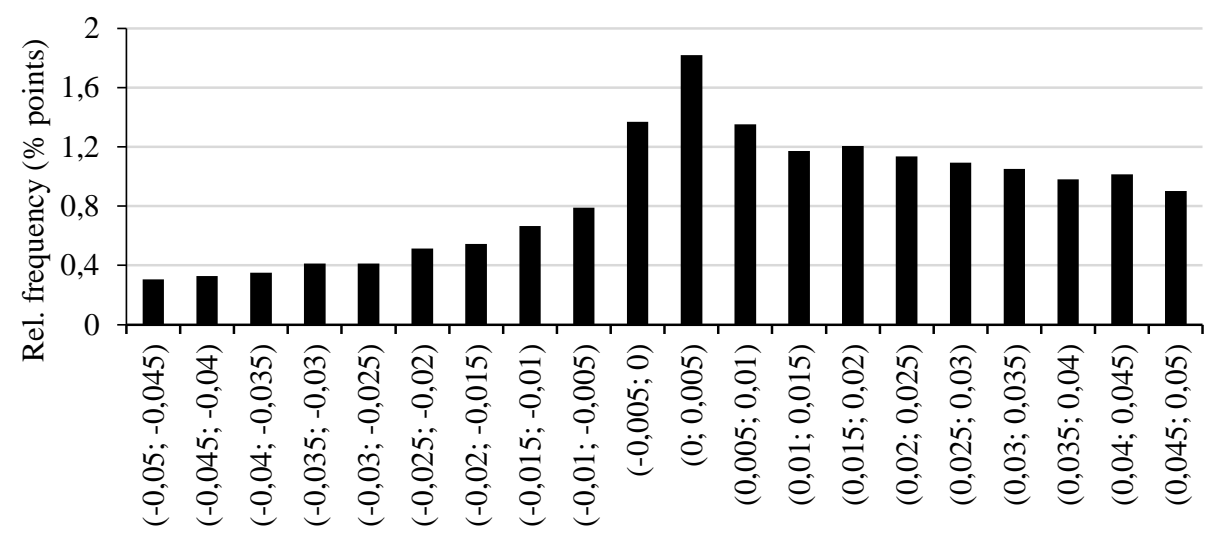

Source: Author. 
Fig. 3 The Czech Republic 2013: Relative frequency of EAT/A bins (\% points)

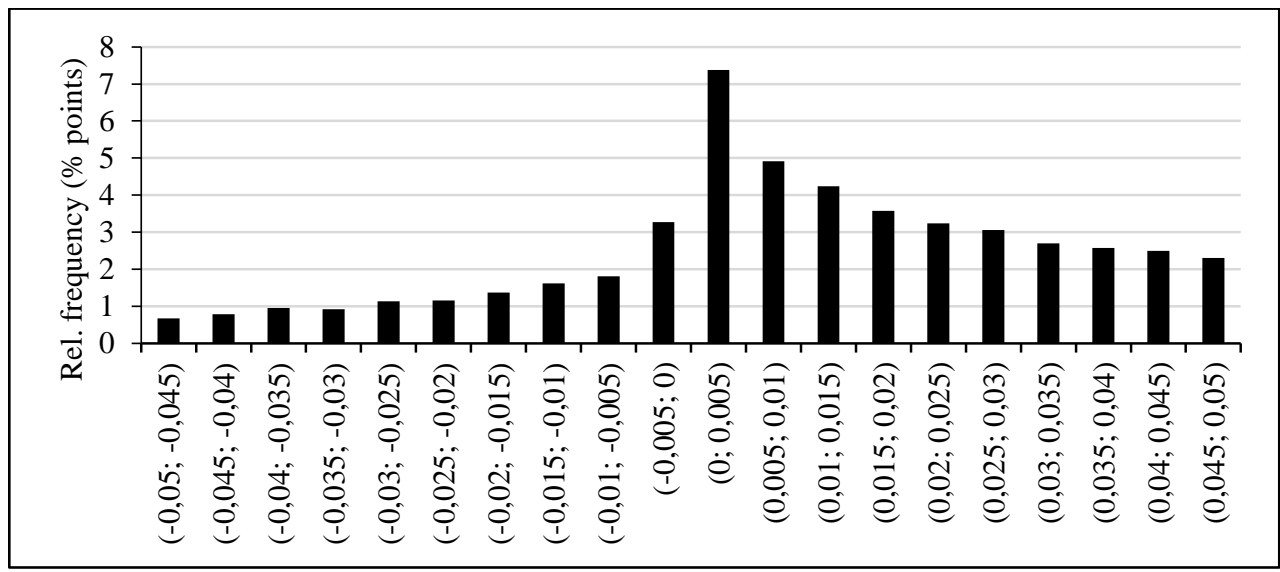

Source: Author.

Table 2 summarizes small profits to small losses ratio as the ratio of relative frequency of the first positive and the first negative bin in the UK, Germany and the Czech Republic. We find mean (median) ratio of 1.364 (1.402) in the UK, 2.720 (2.778) in Germany, and 2.109 (2.127) in the Czech Republic. The table suggests substantial difference in mean (median) ratios between common law and civil law representatives.

Tab. 2 Small profits to small losses ratio

\begin{tabular}{lcccccccccr}
\hline & $\mathbf{2 0 0 6}$ & $\mathbf{2 0 0 7}$ & $\mathbf{2 0 0 8}$ & $\mathbf{2 0 0 9}$ & $\mathbf{2 0 1 0}$ & $\mathbf{2 0 1 1}$ & $\mathbf{2 0 1 2}$ & $\mathbf{2 0 1 3}$ & Mean & Median \\
\hline UK & 1.396 & 1.285 & 1.335 & 1.402 & 1.425 & 1.397 & 1.345 & 1.329 & 1.364 & 1.402 \\
GE & 2.760 & 2.642 & 2.870 & 2.722 & 2.507 & 2.537 & 2.834 & 2.833 & 2.720 & 2.778 \\
CZ & 1.993 & 2.087 & 1.981 & 2.090 & 2.081 & 2.175 & 2.172 & 2.257 & 2.109 & 2.127 \\
\hline
\end{tabular}

Source: Author.

Table 3 shows results of unpaired two sample t-test analysing small profits to small losses ratio from 2006 to 2013 in the UK and the both civil law representatives. The table confirms statistically significant ${ }^{4}$ difference of small profits to small losses ratio between both the UK and Germany, and the UK and the Czech Republic. In other words, the results suggest a significantly lower level of managed earnings in the UK compared to Germany and the Czech Republic. Thus, we reject $\mathrm{H} 1$ since the evidence indicates a significant difference between

4 Statistically significant at $1 \%$ level. 
Svitlík, J. - Žárová, M.: Earnings Discontinuity as the Proxy for Earnings Management: Empirical Study from the UK, Germany and the Czech Republic.

common law and civil law representatives regarding the earnings management level.

Tab. 3 T-test results (small profits to small losses ratio)

\begin{tabular}{lrrr}
\hline & t-statistic & t-test critical value (two-tailed) & \multicolumn{1}{l}{ p-value } \\
\hline UK vs. GE 2006-2013 & -25.989 & 3.250 & $0.000 * * *$ \\
UK vs. CZ 2006-2013 & -19.880 & 3.169 & $0.000 * * *$ \\
\hline
\end{tabular}

Source: Author.

\section{Time-series Analysis of Earnings Distribution}

Besides the static cross-sectional analysis, another interesting feature of empirical research is usually dynamic time-series analysis which tells us more about development of the data. In line with the cross-sectional analysis, we use EAT/A bins of 0.005 width to sort out scaled earnings. In this case we focus on three bins - first positive, first negative and second negative - within each country from 2006 to 2013.

The most interesting features of Figures 4-6 are not the curves per se, but the vertical space between each two curves which depicts change in relative frequency between neighbour bins. Not only may we observe relative frequency difference between neighbour bins for particular year, we may track time changes of these differences.

Germany (see Figure 4) is characterised by (a) big jump from the red to the black numbers, (b) unstable relative frequencies in all the three bins, and (c) relatively synchronic changes in all the three bins (U-shape of all the three curves). These findings suggest that Germany is country where the earnings management level was fairly unstable but kept a relatively high level during the investigated period.

The UK (see Figure 5) is defined by (a) similar change in relative frequency between second negative to first negative bin and first negative to first positive bin, (b) fairly stable relative frequencies in all the three bins, and (c) slightly decreasing (synchronic) trend of all the three bins. According to our findings, the level of earnings management in the UK is slightly decreasing over time.

Time-series analysis of the Czech Republic in Figure 6 portrays (a) significant jump from first negative to first positive bin, (b) unstable relative frequencies in all the three bins, and (c) increasing trend of all the three bins with substantial increase in the first positive bin. The findings suggest an increasing level of earnings management in the Czech Republic.

We find a slight downward trend of the earnings management level in the UK. German companies exhibit mixed results in terms of the earnings management level's development. We find an increasing level of earnings management in the 
Czech Republic. Thus, we reject $\mathrm{H} 2$ since the UK is the only investigated country where we find downward trend of the earnings management level using the methodology of this paper.

\section{Fig. 4 Germany 2006-2013: Relative frequency of EAT/A bins (\% points)}

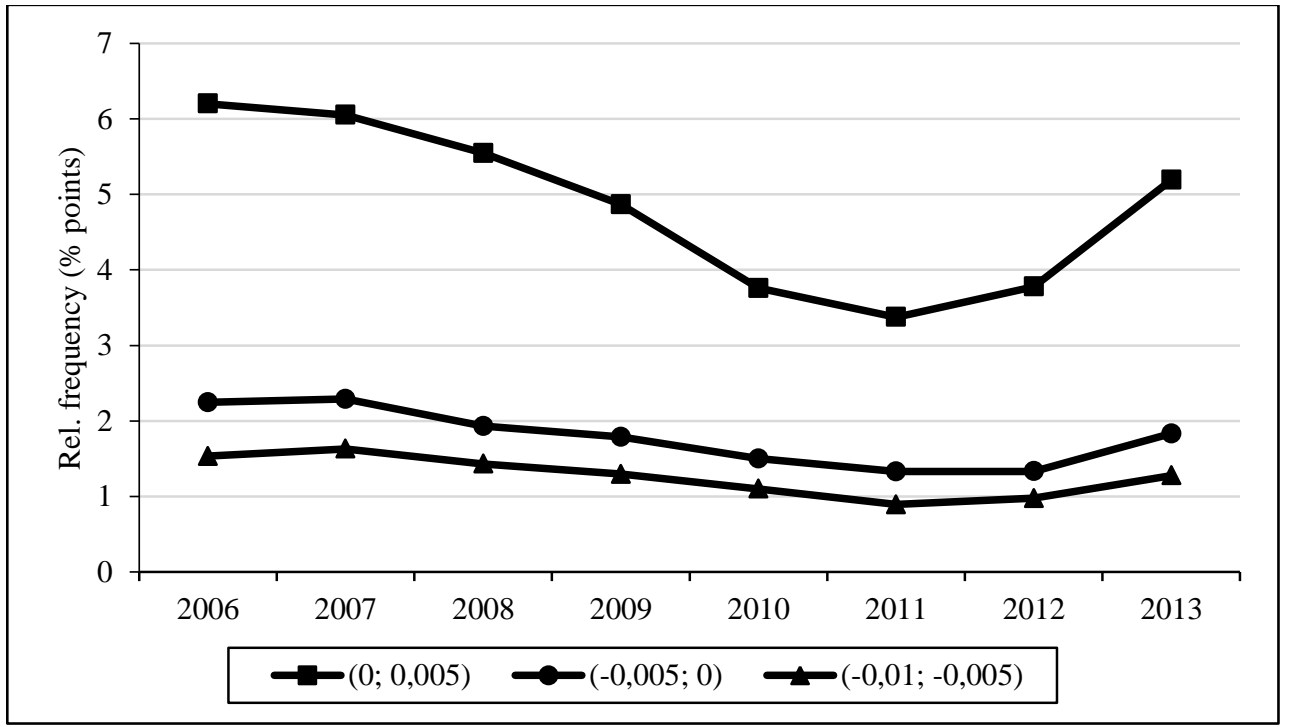

Source: Author.

Fig. 5 The UK 2006-2013: Relative frequency of EAT/A bins (\% points)

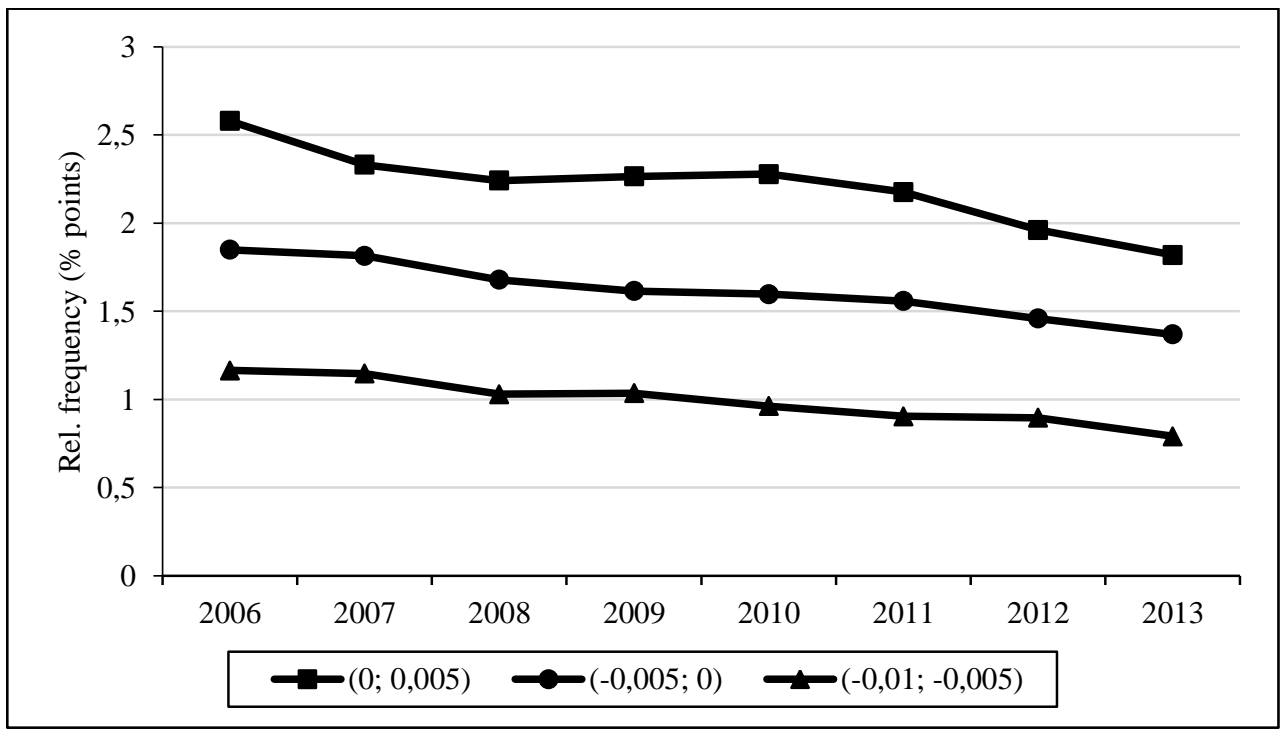

Source: Author. 
Svitlík, J. - Žárová, M.: Earnings Discontinuity as the Proxy for Earnings Management: Empirical Study from the UK, Germany and the Czech Republic.

Fig. 6 The Czech Republic 2006-2013: Relative frequency of EAT/A bins (\% points)

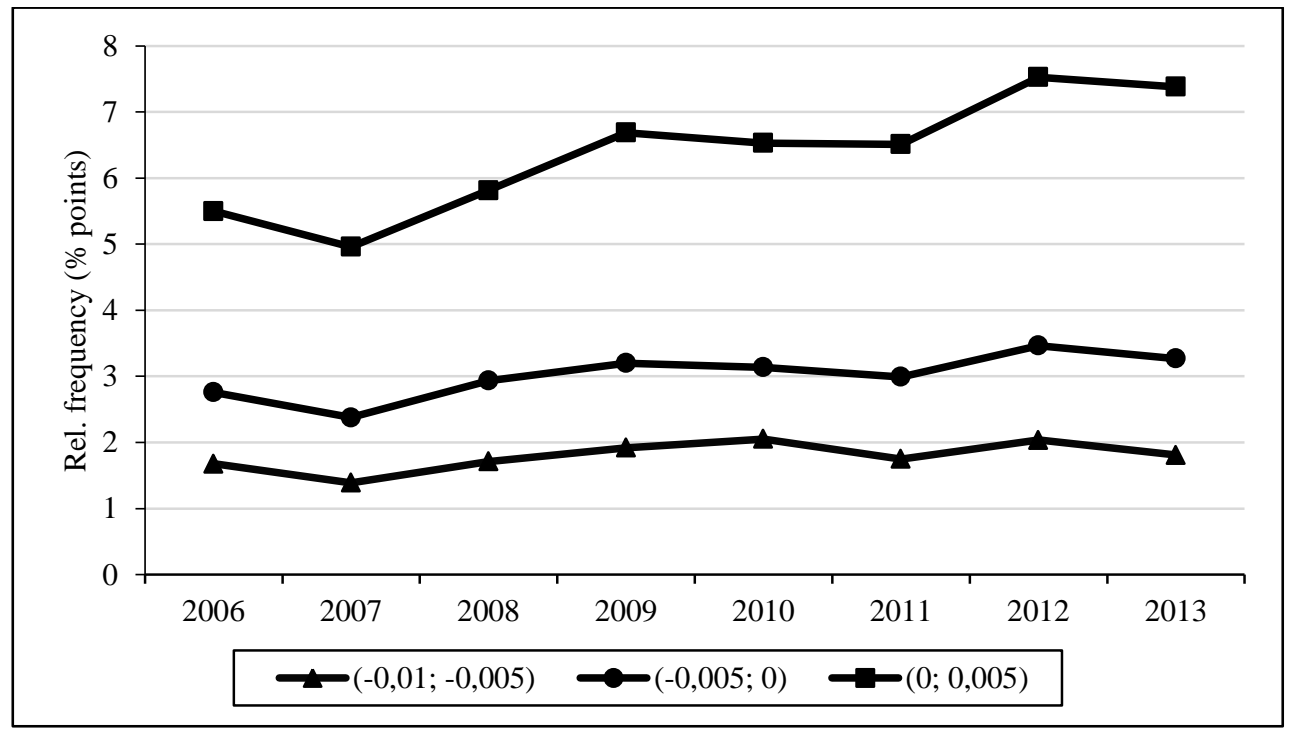

Source: Author.

\section{Results}

Cross-sectional and time-series analyses of the UK, Germany and the Czech Republic lead to distinct inferences for the three European countries. To stress the results, we additionally compute mean relative frequency of given EAT/A bins for the whole time span (2006-2013) within individual countries. First two positive bins and first two negative bins are used in the analysis to get transparent results.

Figure 7 featuring the given bins on horizontal axis and mean relative frequencies on vertical axis shows the earnings distribution around zero level in the UK, Germany and the Czech Republic. Even in case of mean relative frequency for all of the investigated period, we clearly see differences among countries; specifically, substantial jump of relative frequency from first negative to first positive bin occurs within the both civil law countries, while "the roof-shape" does not hold for the UK. Figure 8 goes even further and depicts marginal mean relative frequencies, i.e. differences of relative frequency between neighbour bins. According to the figure, both difference between first and second negative bin, and difference between first and second positive bin is quite similar for all the three countries. As expected, we find substantial difference among countries on the edge of zero level. While there is ,the roof-shape“ of German and Czech curves which depicts high jump from first negative to first positive bin and suggests a relatively 
higher level of earnings management, almost straight slightly downward-trend curve of the UK companies suggests a relatively lower level of managed earnings.

Fig. 7 Mean relative frequency of EAT/A bins 2006-2013 (\% points)

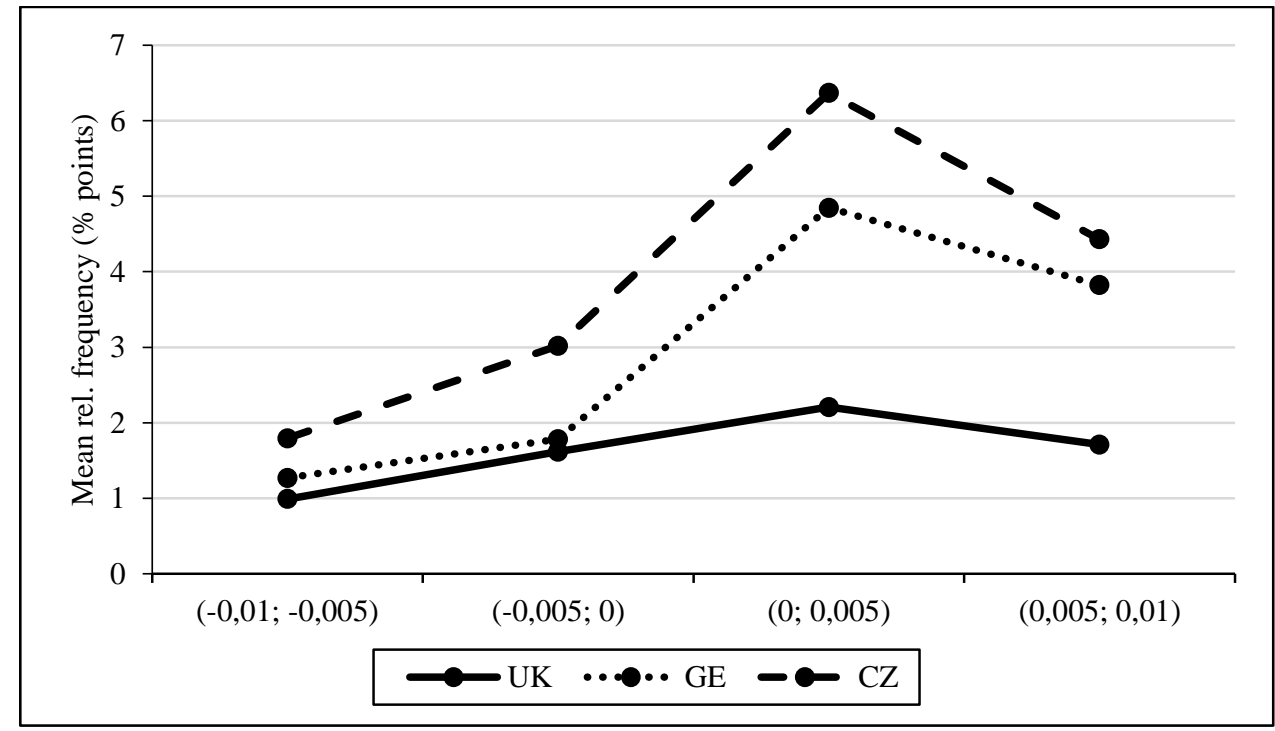

Source: Author.

Fig. 8 Marginal mean relative frequency of EAT/A bins 2006-2013 (\% points)

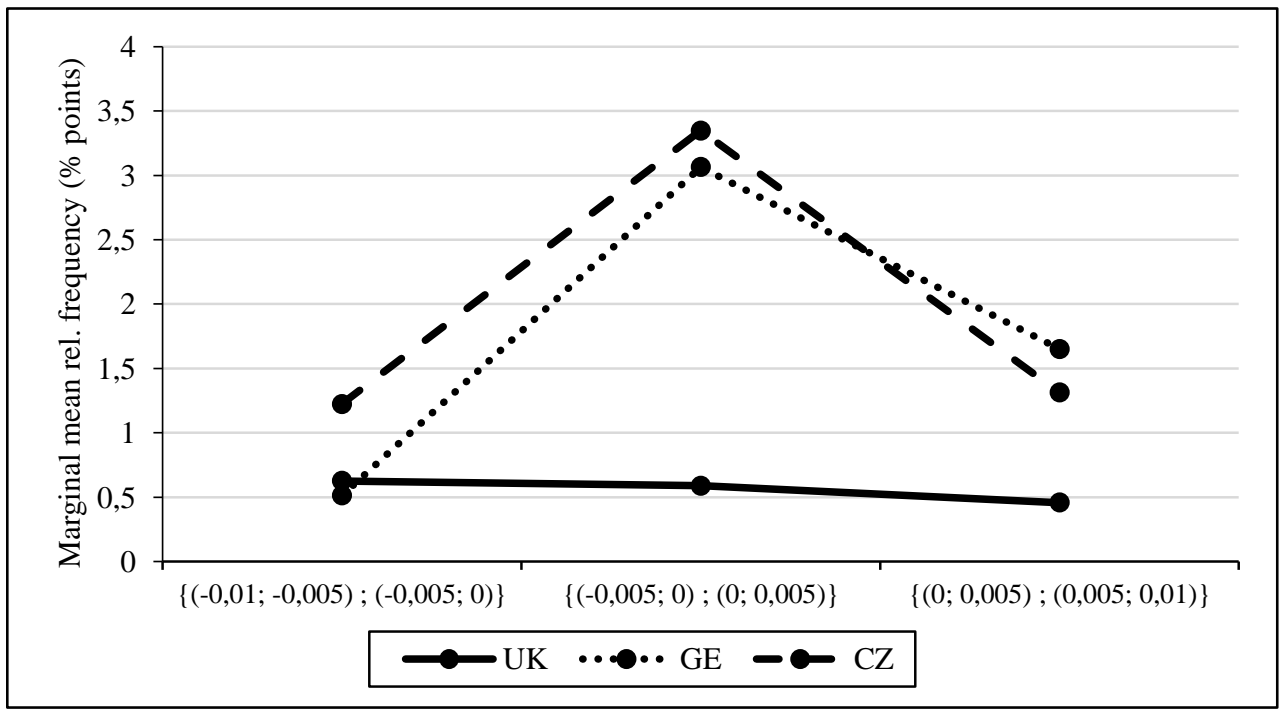

Source: Author. 
Svitlík, J. - Žárová, M.: Earnings Discontinuity as the Proxy for Earnings Management: Empirical Study from the UK, Germany and the Czech Republic.

\section{Conclusion}

We exploit the access to Bureau van Dijk - Amadeus database and perform both cross-sectional and time-series analysis of earnings distribution around zero level in the United Kingdom, Germany and the Czech Republic. We find significant difference between the common law representative and the civil law representatives in terms of the earnings management level detected.

The UK, the common law representative, is low earnings-management country with even slightly decreasing trend of managed earnings. On the other hand, earnings management in Germany, the civil law representative, is of a significantly higher level than in the UK and the trend is relatively mixed over time. Regarding the Czech Republic, another civil law representative, we find a relatively higher level of earnings management compared to the UK and an increasing level of managed earnings from 2006 to 2013. Therefore, we detect a higher level of earnings management in case of civil law representatives compared to the common law one. These findings are basically in line with Geurts (2010) and Burgstahler, Hail and Leuz (2014) and contradictory to Coppens and Peek (2005). Different inferences of Coppens and Peek (2005) might be primarily caused by different time span used in their paper. This reason is supported by the fact that we share similar findings with younger research projects of Geurts (2010) and Burgstahler, Hail and Leuz (2014).

The paper suggests that despite convergence process of common law and civil law, there still exist differences between the two legal families in terms of certain economic characteristics; specifically, earnings management of companies. Higher level of earnings management in civil law countries is perhaps connected with higher book-tax alignment of such countries. This suggests some connection between the book-tax alignment level and the earnings management level of a country.

Moreover, analysis of the Czech Republic shows increasing the earnings management level. This might serve as warning for Czech legislators and users of financial reports saying that reported earnings of companies indicate rather lowering quality.

Analysis of broad data sample of the three European economies gives reliable results; nevertheless, there is couple of limitations of our study. First, companies of various economic sectors, sizes, and legal forms are included in the data sample, thus the results might not hold for each individual category. Second, timeseries analysis of our research might be slightly biased by the period of the global financial crisis; on the other hand, the results basically hold for all the pre-crisis, crisis and post-crisis period.

Future research might, for instance, apply the same methodology on different European countries. Another research avenues might employ company-specific 
characteristics to the research design, or use matched samples based on firm-size or economic sectors.

\section{References}

Altintas, N., Yilmaz, F., 2012. The Accounting Profession: A Descriptive Study of the Common and Code Law Countries. Journal of Modern Accounting and Auditing 8, 932-950.

Aussenegg, W., Inwinkl, P., Schneider, G., 2009. Earnings management and accounting standards in Europe. Proceedings of the 2009 MFA Annual Meeting, Chicago, Illinois, USA.

Bromwich, M., Hopwood A. G., 1992. Accounting and the Law. Prentice hall, London.

Burgstahler, D. C., Dichev, I., 1997. Earnings management to avoid earnings decreases and losses. Journal of Accounting and Economics 24, 99-126. DOI: 10.1016/s0165-4101(97)00017-7.

Burgstahler, D. C., Hail, L., Leuz, C., 2014. The Importance of Reporting Incentives: Earnings Management in European Private and Public Firms. The Accounting Review 81, 983-1016. DOI: 10.2308/accr.2006.81.5.983.

Coppens, L., Peek, E., 2005. An analysis of earnings management by European private firms. Journal of International Accounting, Auditing and Taxation 14, 1-17. DOI: 10.1016/j.intaccaudtax.2005.01.002.

Dainow, J., 2013. The Civil Law and The Common Law: Some Points of Comparison. The American Journal of Comparative Law 15, 419-435. DOI: $10.2307 / 838275$.

Day, R., 2000. UK accounting regulation: An historical perspective. Working Paper. Bournemouth University School of Finance and Law, Poole, UK.

Dechow, P. M., Sloan, R. G., Sweeney, A. P., 1995. Detecting Earnings Management. The Accounting Review 70, 193-225.

Geurts, M., 2010. Earnings management in European private firms. Master's thesis. University of Amsterdam, The Netherlands.

Harris, D., Shi, L., 2014. Why Are Earnings Distributions Kinky: Upwards Earnings Management by Small-Profit Firms or Income Smoothing by Many Firms? Working paper. Syracuse University, New York, USA.

Hayn, C., 1995. The Information Content of Losses. Journal of Accounting and Economics 20, 125-153. DOI: 10.1016/0165-4101(95)00397-2.

Hermida, J., 2004. Convergence of civil Law and common Law Contracts in the Space Field. Hong Kong Law Journal 34, 32. DOI: 10.2139/ssrn.1429664. 
Svitlík, J. - Žárová, M.: Earnings Discontinuity as the Proxy for Earnings Management: Empirical Study from the UK, Germany and the Czech Republic.

Jindrichovska, I., 2004. International Differences in Accounting: The Birth of an Accounting Harmonization Process? Working Paper for the conference "Trendy ve vyuce ucetnictvi na vysokych skolach neuniverzitniho smeru" organized by Soukroma vysoka skola ekonomickych studii, Prague.

Jones, J. J., 1991. Earnings Management During Import Relief Investigations. Journal of Accounting Research 29, 193. DOI: 10.2307/2491047.

Kang, S., 1999. A Conceptual and Empirical Evaluation of Accrual Prediction Models. Working paper. George Washington University, Washington D.C., USA.

La Porta, R., Lopez-de-Silanes, F., Shleifer, A., Vishny, R. W., 1998. Law and Finance. Journal of Political Economy 106, 1113-1155. DOI: 10.1086/250042.

Leuz, C., Nanda, D., Wysocki, P. D., 2003. Earnings management and investor protection: an international comparison. Journal of Financial Economics 69, 505-527. DOI: 10.1016/s0304-405x(03)00121-1.

Lindahl, F., Schadewitz H., 2013. Are Legal Families Related to Financial Reporting Quality? Abacus: A Journal of Accounting, Finance and Business Studies 49, 242-267. DOI: 10.1111/abac.12008.

Marinakis, P., 2011. An investigation of earnings management and earnings manipulation in the UK. PhD thesis. University of Nottingham, UK.

Messitte, P. J., 1999. Common law v. civil law systems. USIS, Issues of Democracy, September 1999.

Mikova, T., 2015. IFRS Influence on Financial Reporting Quality. PhD thesis. University of Economics in Prague, the Czech Republic.

Moreira, J. A. C., Pope, P. F., 2007. Earnings Management to Avoid Losses: a cost of debt explanation. Working paper. Universidade do Porto, Portugal.

Nobes, C., Parker, R. H., 2012. Comparative international accounting. Pearson Education, London.

Roberts, C., Weetman, P., Gordon, P., 2005. International Financial Reporting: A Comparative Approach. Pearson Education, London. 